DOI: $10.30525 / 978-9934-588-61-7-16$

Tunitska Yu. M.

Ph.D. in Economics, Independent Researcher

Syerova L. P.

Ph.D. in Economics,

Senior Lecturer at the Department of International Management

Kyiv National University of Trade And Economics

Ladychenko K. I.

Ph.D. in Economics,

Senior Lecturer at the Department of World Economy

Kyiv National University of Trade And Economics

\title{
CURRENT TRENDS IN UKRAINE'S COOPERATION WITH INTERNATIONAL ORGANIZATIONS
}

\section{Summary}

The work explores the nature and functioning mechanism of international organizations (IOs). The role of IOs, legal regulations and principles of performance, the peculiarities of their functional departmentation are defined. Modern tendencies of IOs' development both worldwide and in Ukraine are revealed. Special aspects and consequences of cooperation with international financial organizations are studied. Particular issues associated with the interaction of the Agro-industrial complex of Ukraine with sectoral international organizations are determined. The classification of IOs is improved by highlighting the criteria: "compliance with changes in the international context» (IOs, the activities of which correspond to modern realities and those in need of reorganization); "a place in the value chain of products of a certain industry" (organizations that directly affect the production and processing of raw materials, as well as those that ensure the effective development of foreign trade (external logistics, marketing and sales).

\section{Introduction}

International organizations (IOs) are strategically important subjects of today's global economy given their ability to accumulate strong financial, production, scientific and technological potential, the development of international strategies for the economic progress of the countries worldwide and the global financial system, international trade, innovative processes. Cooperation of Ukraine with IOs is one of the priority areas for the foreign policy development strategy in terms of overcoming the crisis.

Today, the cooperation of Ukraine with sectoral international organizations, for example, in the field of agriculture, is especially significant, taking into account the strategic objectives of its development: completion of land reform; 
elimination of unprofitable, inefficient agricultural enterprises; overcoming corruption in the field of state regulation, increasing the income of those employed in the agro-industrial complex by liberalizing the labor market and improving the qualification of employees; decentralization, rural development and support for small business.

The works of domestic and foreign scientists are devoted to the study of theoretical and methodological aspects and problems of the modern development of international organizations. In particular, Baluta I.V. [1] and Ryneiska L.S. [2] analyzed the role of international organizations in the globalization process and the formation of international economic development strategies. Sazonets I.L. [3] investigated the role of NGOs in the regulation of international economic relations. Khomaiko K. [4] studied the cooperation of public authorities with IOs, Horbatiuk Ye. [5] investigated the activities of international intergovernmental organizations of the global type in the system of socio-humanistic security, Hodovanyk Ye.V. and Pokatovych M.O. [6] carried out the studies on strengthening the role of IOs in counteracting acts of aggression and directions of their reform. The works of Dereval Yu. [7] have been devoted to the issue of cooperation with the ILO. Zamkovyi R.V. [8] studied the professional engagement and interaction of Ukraine with the International Organization for Standardization. The effects of cooperation with international financial organizations on the national economy have been the subject of researches by Klymenko K.V. and Savostianenko M.V. [9], Kolosova M.P. [10], Tereshchenko H.M. [11] and others.

Thus, researchers, most commonly, tend to analyze the activity of international organizations in specific spheres of economy. At the same time, there is no comprehensive approach that would cover the improvement of the theoretical and methodological apparatus of IOs and analysis of current trends in the development of the studied institutions of various types, in particular, financial and sectoral, including in the field of agriculture.

The purpose of the article is to determine the theoretical and methodological foundations of the functioning mechanism of international organizations and substantiation of new criteria for their classification, study of current developmental features and problems in cooperation between Ukraine and IOs in various fields.

\section{Part 1. Theoretical foundations of the functioning mechanism of international organizations}

Today, the definition of international organizations distinguishes the institutional approach, according to which international organizations are the permanent institution of comprehensive international relations, which arises between the three parties (states) and embodies the agreed goals, activities, as well as, directly, political and legal norms [4].

Domestic and foreign scholars classify IOs according to the following criteria: membership of subjects of international relations and legal status of 
the organization, geographical coverage, functional orientation, nature of activities, the procedure for joining the organization, etc. (Figure 1).

All IOs in the process of their activities vigorously interact with each other and form a single international system, the main purpose of which is to assist its participants in terms of economic development, the unification of general rules regulating international relations.

International organizations perform various competences: subject, covering general (political, military and political) and special (social, economic, cultural, financial, etc.) aspects, according to the statutory documents defining the core activities of an IO; regulatory, that determines the legal validity of the decisions of an IO on its subject competence, and the bodies of international organizations within their powers on the subject competence consider and make decisions, investigate identified problems and provide recommendations for overcoming them, sign international agreements, settle disputes between members; general, which includes the implementation of powers aimed at achieving its main goals and objectives; special - solving administrative and technical issues that are not directly related to the implementation of the main objectives of an IO; external - the implementation of external relations strategies with states no matter if they have the status of a member of an IO, international and non-governmental organizations, individuals and legal entities; internal - solving internal issues concerning the activity of a particular IO, including financial, administrative, technical, etc.

According to the allocation of powers and authority in the constituent document, there are distinguished direct (unambiguous powers of the bodies of an organization, enshrined in the text of the constituent act) and the promised competence.

In the course of their work, IOs perform certain functions. The regulatory function is to make decisions aimed at implementing the goals and principles of the organization, in the standards of conduct established for member countries, which have moral and political or legal significance.

By its operational function, the IO performs its duties independently, using inhouse human and material resources, while, when performing regulatory and control functions, the organization impels member states to fulfil those tasks through political pressure. The control function consists in the executing of organized control over the compliance of the behavior of its members with international law to encourage the implementation of the provisions of the relevant documents, under the principle of respect for state sovereignty without interference in the internal affairs of states.

The coordination and information function is to inform the international community about the goals, policies and activities of the international organization.

The advisory function is manifested in the preparation and conduct of consultative work for the States and institutions concerned. Consultations consist of several phases: «comparison», «negotiations»; "adoption of recommendations by the organization». 
An international organization can be created as a result of the agreed will of the countries, it is fixed either in an international agreement or in a decree of an existing organization. The constituent document is adopted, the structure of the organization is formed, and the highest governing body is created. Special preparatory bodies are responsible for forming the structure of the IO. They develop draft rules and procedures for the newly created bodies, set up headquarters, set the agenda for the main bodies, and develop agreements and recommendations related to the agenda.

All IO bodies have a certain structure and composition, a defined decisionmaking procedure.

The financial resources of the IO consist mainly of contributions from member countries and are directed to common goals.

In the structure of the IO, the bodies form a kind of meso-level of the organization, which provides a link between the macro and micro levels (member states of the IO and individuals, including representatives of states in the IO, staff, experts, respectively).

According to the ideal model of the shaping and activity of the IO bodies, they rely on the rational reasons of the IO members and function in order to achieve the main tasks of the organization, in case of having adequate resources, and are fully controlled by the organization and its members. In practice, IO bodies are formed as a result of the interaction of the adverse interests of different countries, pressure groups and social forces, which determines their size, composition and competence, etc.

By their functions, bodies in international organizations are divided into main, executive, administrative, control and subsidiary; by frequency of meetings: permanent and sessional; by the nature of membership: intergovernmental, interparliamentary, consisting of persons in a personal capacity, or of national committees and groups; by a number of members: bodies of entire and limited membership; by the nature of the constitution: elected and non-elected; on the legal basis of creation: statutory, conventional, created by the decree of other bodies; by geographical location: internal and external bodies; by functions: decision-making bodies and those that control the activities of the organization.

Bodies in the IO accept a decision on the initiative of one or a group of states, bodies or officials. The constituent documents of international organizations mostly contain definitions of decisions in the form of resolutions, decrees or regulations. However, in practice, first of all, guidelines, recommendations, rules and regulations, etc. are accepted.

Decisions of international organizations are classified according to the following criteria: geographical area, legal status, scope, direction, method of acceptance, functional authorities, etc. The decision-making procedure includes the following steps: raising a question, considering a question and developing a resolution, accepting a decision. In this case, the methods of weighted voting, majority, consensus, and unanimous, are used. 


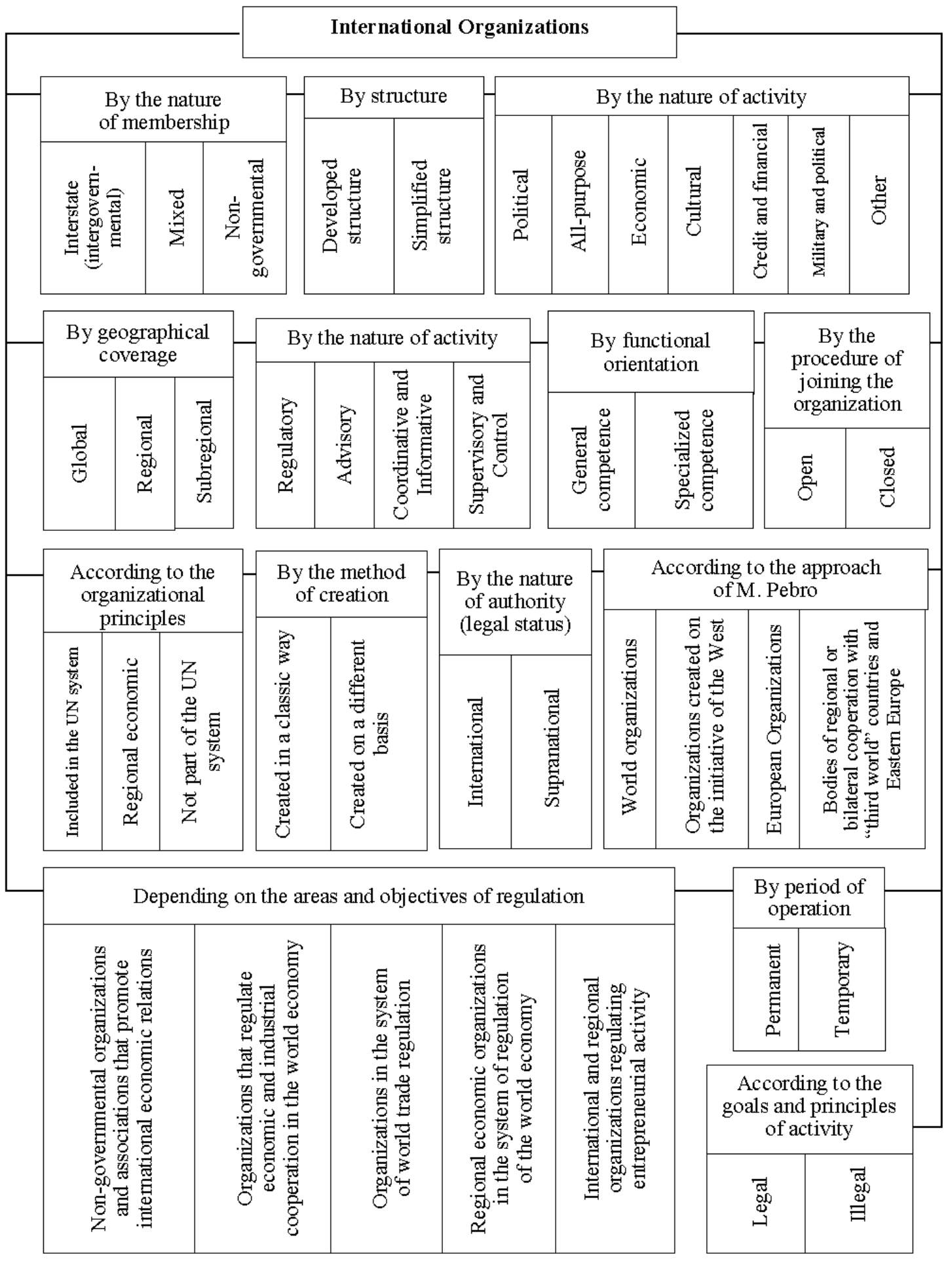

Figure 1. Classification of international organizations

Source: compiled by the authors on the basis of $[1 ; 3 ; 12 ; 13]$

Part 2. Cooperation of Ukraine with International Financial Institutions (IFIs)

Today, there is observed an increasing role of international nongovernmental organizations in the world. In the context of global 
informational confrontation, they influence world politics via mobilization of public opinion, the pressure on the interstate organizations and individual countries to address specific problems, monitor government activity in different spheres of public life and control the fulfillment of the obligations taken [1].

The degree of the monetary system performance efficiency in the world and individual countries depends on the activities of International Financial Institutions (IFIs). However, as a rule, they contribute to the economic progress of the countries, to the extent consistent with their ideology as representatives of developed countries, which is the reason for the asymmetry of the economic system, the uneven distribution of the globalization benefits between countries and its subjects [14].

During its membership in the IMF (since 1992), Ukraine received 22410.76 million SDR (32 900 million USD) (see Table 1). This cooperation, aimed at stabilizing Ukraine's financial system and carrying out reforms towards sustainable economic development, provides an opportunity to receive funding from other IFIs, such as the World Bank, EBRD, EIB and others, as well as from the governments of the USA, the EU, Germany, Canada, Japan.

Table 1

The main periods of cooperation between Ukraine and the IMF

\begin{tabular}{|c|c|c|}
\hline Period (years) & Credit programs & Loan volumes \\
\hline 1. 1994-1995 & System transformational loan & $\begin{array}{l}498.7 \text { million SDR, } \\
\text { or } 763.1 \text { million USD }\end{array}$ \\
\hline 2 1995-1998 & $\begin{array}{l}\text { Three one-year Stand-by } \\
\text { Arrangements }\end{array}$ & $\begin{array}{l}1318.2 \text { million SDR (1 } 935 \\
\text { million USD) }\end{array}$ \\
\hline $3.1998-2002$ & Extended Fund Facility (EFF) & $\begin{array}{l}1193.0 \text { million SDR (or } 1591.0 \\
\text { million USD) }\end{array}$ \\
\hline 4. $2002-2008$ & $\begin{array}{l}\text { «Precautionary» } \\
\text { Stand-by Agreement. }\end{array}$ & $\begin{array}{l}411.6 \text { million SDR, } 30 \% \text { of } \\
\text { Ukraine's quota, or } 600 \text { million } \\
\text { USD }\end{array}$ \\
\hline 5. $2008-2013$ & $\begin{array}{l}\text { Stand-by Agreement (SBA) dated } \\
\text { November 5, } 2008\end{array}$ & $\begin{array}{l}11 \text { billion SDR (16.4 billion } \\
\text { USD) }\end{array}$ \\
\hline \multirow{2}{*}{ 6. 2014-2017 } & $\begin{array}{l}\text { April 2014. A new two-year } \\
\text { exceptional access Stand-By } \\
\text { Arrangement (SBA) }\end{array}$ & $\begin{array}{l}10.976 \text { billion SDR, } \\
\text { or almost } 17.1 \text { billion USD }\end{array}$ \\
\hline & March 11, 2015. EFF for four years & $\begin{array}{l}\text { 12.348 billion SDR or almost } \\
17.5 \text { billion USD or } 15.5 \text { billion } \\
\text { EUR }\end{array}$ \\
\hline \multirow[t]{2}{*}{ 7. 2018-2019 } & $\begin{array}{l}\text { October 19, 2018. A } 14 \text { months } \\
\text { Stand-by Arrangement, which } \\
\text { replaced the EFF Program } \\
\text { approved in March } 2015\end{array}$ & 3.9 billion USD \\
\hline & December 18, 2018 - the new SBA & $\begin{array}{l}1 \text { billion SDR } \\
\text { (about } 1.38 \text { billion USD). }\end{array}$ \\
\hline
\end{tabular}

Source: compiled by the authors based on [17] 
Although, Ukraine has not met the obligatory requirements of the IMF to launch a new three-year program of expanded financing of 5.5 billion USD, in December 2019, a new 18-month program has been approved to help Ukraine's economy and health care system to overcome the effects of the pandemic. Indeed, the ineffective WHO decisions in countering the development of the COVID-19 pandemic were disastrous for the economy of Ukraine and the entire world. A drop in production and foreign trade, declining living standards against the sharpening of political turmoil and environmental degradation is the new reality for domestic enterprises to function in.

In total 80 countries with emerging markets applied to the IMF for assistance by 20 billion USD. Having assessed the financial needs of the markets at 2.5 trillion USD [15], the IMF approved the immediate relief of the debt burden for 25 IMF member countries under the IMF's revamped Catastrophe Containment and Relief Trust (CCRT) as part of the Fund's response to help address the impact of the COVID-19 pandemic [16].

Ukraine implements joint projects with the European Bank for Reconstruction and Development (EBRD) and the European Investment Bank (EIB). The largest amounts of funds are directed to the renovation of roads and highways, improving the safety of nuclear power plants and hydropower plants.

The total amount of funds provided by the EIB to Ukraine is over 6.4 billion EUR. In the public sector, 20 projects are funded for a total of 4.089 billion EUR, 651.46 million of which have already been utilized (see Table 2) [18].

Table 2

\section{Disbursement of funds for the EIB projects in the public sector of Ukraine}

\begin{tabular}{|c|c|c|c|c|c|}
\hline \multirow{2}{*}{ № } & \multirow{2}{*}{$\begin{array}{c}\text { Agreement } \\
\text { number, date } \\
(\mathrm{dd} / \mathrm{mm} / \mathrm{yyyy})\end{array}$} & \multirow{2}{*}{ Project title } & \multirow{2}{*}{ 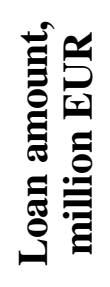 } & \multicolumn{2}{|c|}{$\begin{array}{l}\text { Disbursed at } \\
\text { April 1, 2020 }\end{array}$} \\
\hline & & & & 总局 & $s^{\circ}$ \\
\hline \multicolumn{6}{|c|}{ Projects under implementation } \\
\hline 1 & $\begin{array}{l}\text { № } 81.423 \mathrm{dd} \\
25.10 .2013\end{array}$ & $\begin{array}{l}\text { DNIPROPETROVSK METRO } \\
\text { CONSTRUCTION COMPLETION }\end{array}$ & 152 & 19.33 & 12.72 \\
\hline 2 & $\begin{array}{c}\text { № 31.177 dd } \\
21.09 .2012\end{array}$ & $\begin{array}{l}\text { HYDRO POWER PLANTS } \\
\text { REHABILITATION }\end{array}$ & 200 & 44 & 22.00 \\
\hline 3 & $\begin{array}{l}\text { № } 24.668 \mathrm{dd} \\
20.10 .2008\end{array}$ & $\begin{array}{l}\text { RIVNE-KYIV HIGH VOLTAGE } \\
\text { LINE. Construction of a } 350 \mathrm{~km} \text { long } \\
750 \mathrm{kV} \text { AC transmission line. }\end{array}$ & 150 & 102.45 & 68.30 \\
\hline 4 & $\begin{array}{l}\text { № } 31.143 \mathrm{dd} \\
16.09 .2011\end{array}$ & $\begin{array}{l}\text { 750KV ZAPORIZHZHIA-KAKHOV- } \\
\text { SKA TRANSMISSION LINE. } \\
\text { Construction of (1) a } 190 \mathrm{~km} \text { long } 750 \\
\mathrm{kV} \text { AC transmission line, (2) a new }\end{array}$ & 175 & 72.7 & 41.54 \\
\hline
\end{tabular}




\begin{tabular}{|c|c|c|c|c|c|}
\hline \multirow{2}{*}{ № } & \multirow{2}{*}{$\begin{array}{c}\text { Agreement } \\
\text { number, date } \\
(\mathrm{dd} / \mathrm{mm} / \mathrm{yyyy})\end{array}$} & \multirow{2}{*}{ Project title } & \multirow{2}{*}{ 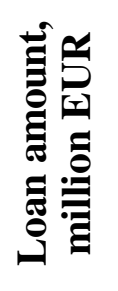 } & \multicolumn{2}{|c|}{$\begin{array}{l}\text { Disbursed at } \\
\text { April 1, } 2020\end{array}$} \\
\hline & & & & 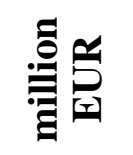 & 8 \\
\hline & & $\begin{array}{l}750 / 330 \mathrm{kV} \text { substation at Kakhovska, } \\
\text { and (3) 330kV line interconnections } \\
\text { into the existing } 330 \mathrm{kV} \text { network. }\end{array}$ & & & \\
\hline 5 & $\begin{array}{c}\text { № } 81.420 \mathrm{dd} \\
01.12 .2014\end{array}$ & $\begin{array}{l}\text { URENGOY- POMARY- } \\
\text { UZHGOROD GAS PIPELINE } \\
\text { infrastructure rehabilitation project. }\end{array}$ & 150 & 0 & 0.00 \\
\hline 6 & $\begin{array}{c}\text { № } 26.131 \mathrm{dd} \\
27.05 .2011\end{array}$ & $\begin{array}{l}\text { EUROPEAN ROADS UKRAINE II } \\
\text { (Rehabilitation and improvement of } \\
\text { about } 350 \mathrm{~km} \text { of highways radiating } \\
\text { from Kyiv in central Ukraine) }\end{array}$ & 450 & 212.91 & 47.31 \\
\hline 7 & $\begin{array}{c}\text { № } 81.421 \mathrm{dd} \\
07.05 .2014\end{array}$ & $\begin{array}{l}\text { BESKYD RAILWAY TUNNEL } \\
\text { (Construction project) }\end{array}$ & 55 & 54.77 & 99.58 \\
\hline 8 & $\begin{array}{l}\text { № 85.103 dd } \\
11.11 .2016\end{array}$ & $\begin{array}{l}\text { UKRAINE URBAN PUBLIC } \\
\text { TRANSPORT FL (Upgrading of } \\
\text { public transport infrastructure in } 20 \\
\text { municipalities) }\end{array}$ & 200 & 0 & 0.00 \\
\hline 9 & $\begin{array}{c}\text { № } 25.474 \text { dd } \\
02.02 .2010\end{array}$ & $\begin{array}{l}\text { MYKOLAYIV VODOKANAL } \\
\text { (Water supply and sewerage system } \\
\text { development) }\end{array}$ & 15.54 & 5 & 32.18 \\
\hline 10 & $\begin{array}{l}\text { № } 84.160 \mathrm{dd} \\
22.12 .2014\end{array}$ & $\begin{array}{l}\text { UKRAINE EARLY RECOVERY } \\
\text { (Framework loan to support priority } \\
\text { investments in the recovery of areas } \\
\text { affected by the conflict in the } \\
\text { Ukrainian region of Donbas) }\end{array}$ & 200 & 47 & 23.50 \\
\hline 11 & $\begin{array}{c}\text { № } 82.844 \text { dd } \\
24.12 .2014\end{array}$ & $\begin{array}{l}\text { APEX LOAN FOR SMES \& MID- } \\
\text { CAPS (UKRAINE) }\end{array}$ & 400 & 93 & 23.25 \\
\hline 12 & $\begin{array}{l}\text { № } 81.425 \mathrm{dd} \\
23.07 .2015\end{array}$ & $\begin{array}{l}\text { UKRAINE MUNICIPAL } \\
\text { INFRASTRUCTURE } \\
\text { PROGRAMME }\end{array}$ & 400 & 0.3 & 0.08 \\
\hline 13 & $\begin{array}{c}\text { № 85.055 dd } \\
28.12 .2015\end{array}$ & $\begin{array}{l}\text { UKRAINE AGRI-FOOD APEX } \\
\text { LOAN }\end{array}$ & 400 & 0 & 0.00 \\
\hline 14 & $\begin{array}{c}\text { № 84.172 dd } \\
19.12 .2016\end{array}$ & UKRAINE HIGHER EDUCATION & 120 & 0 & 0.00 \\
\hline 15 & $\begin{array}{l}\text { № } 81.843 \mathrm{dd} \\
19.12 .2016\end{array}$ & $\begin{array}{l}\text { UKRAINE RAILWAY } \\
\text { MODERNIZATION (PJSC «Ukrzaliz- } \\
\text { nytsia» infrastructure modernization) }\end{array}$ & 150 & 0 & 0.00 \\
\hline 16 & $\begin{array}{c}\text { № 85.847 dd } \\
11.12 .2017 \\
\end{array}$ & KHARKIV METRO EXTENSION & 160 & 0 & 0.00 \\
\hline 17 & $\begin{array}{c}\text { № 86.980 dd } \\
09.07 .2018 \\
\end{array}$ & UKRAINE URBAN ROAD SAFETY & 75 & 0 & 0.00 \\
\hline \multicolumn{6}{|c|}{ Projects under preparation } \\
\hline 18 & $\begin{array}{l}\text { № } 87.554 \mathrm{dd} \\
24.05 .2018\end{array}$ & $\begin{array}{l}\text { SUBSTATIONS RELIABILITY } \\
\text { ENHANCEMENT PROGRAMME }\end{array}$ & 136 & 0 & 0.00 \\
\hline 19 & $\begin{array}{c}\text { № } 87.617 \mathrm{dd} \\
17.12 .2018\end{array}$ & $\begin{array}{l}\text { UKRAINE TRANSPORT } \\
\text { CONNECTIVITY }\end{array}$ & 50 & 0 & 0.00 \\
\hline
\end{tabular}




\begin{tabular}{|c|c|c|c|c|c|}
\hline \multirow{2}{*}{ № } & \multirow{2}{*}{$\begin{array}{c}\text { Agreement } \\
\text { number, date } \\
(\mathrm{dd} / \mathrm{mm} / \mathbf{y y y y})\end{array}$} & \multirow{2}{*}{ Project title } & \multirow{2}{*}{ 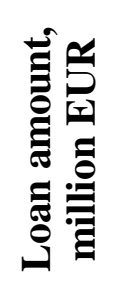 } & \multicolumn{2}{|c|}{$\begin{array}{l}\text { Disbursed at } \\
\text { April 1, 2020 }\end{array}$} \\
\hline & & & & 氜电电 & $b^{2}$ \\
\hline \multirow[t]{2}{*}{20} & $\begin{array}{l}\text { № } 89.419 \mathrm{dd} \\
22.11 .2019\end{array}$ & $\begin{array}{l}\text { EUROPEAN ROADS UKRAINE III } \\
\text { (TEN-T network) }\end{array}$ & 450 & 0 & 0.00 \\
\hline & & TOTAL & 4088.54 & 651.46 & 15.93 \\
\hline
\end{tabular}

Source: compiled by the authors based on [18]

The EBRD is one of the largest institutional investors in Ukraine. The total amount of financing allocated to Ukraine is 14.7 billion EUR (454 projects). As of the beginning of 2020, 7 joint projects with the EBRD in the total amount of 1552.0 million EUR have been under implementation. The share of funds used is $51.2 \%$ of the total loans (see Table 3) [16].

Table 3

Disbursement of funds for the EBRD projects in the public sector of Ukraine

\begin{tabular}{|c|c|c|c|c|c|}
\hline \multirow[t]{2}{*}{ № } & \multirow{2}{*}{$\begin{array}{c}\text { Project } \\
\text { number, date } \\
(\mathrm{dd} / \mathrm{mm} / \mathbf{y y y y})\end{array}$} & \multirow[t]{2}{*}{ Project title } & \multirow{2}{*}{$\begin{array}{l}\text { Loan } \\
\text { amount, } \\
\text { million } \\
\text { EUR }\end{array}$} & \multicolumn{2}{|c|}{$\begin{array}{c}\text { Disbursed at } \\
\text { March 31, } \\
\mathbf{2 0 2 0}\end{array}$} \\
\hline & & & & $\begin{array}{c}\text { million } \\
\text { EUR }\end{array}$ & $\%$ \\
\hline 1 & $\begin{array}{c}46411 \mathrm{dd} \\
11.12 .2017\end{array}$ & Kharkiv Metro Extension & 160.00 & 1.60 & 1.00 \\
\hline 2 & $\begin{array}{c}47947 \mathrm{dd} \\
30.12 .2015\end{array}$ & $\begin{array}{l}\text { Hydro Power Plants } \\
\text { Rehabilitation Project }\end{array}$ & 180.00 & 47.63 & 26.46 \\
\hline 3 & $\begin{array}{c}42608 \mathrm{dd} \\
15.12 .2014\end{array}$ & $\begin{array}{l}\text { NAK Naftogaz Emergency } \\
\text { Pipeline Upgrade and } \\
\text { Modernisation (Urengoy- } \\
\text { Pomary-Uzhgorod gas pipeline } \\
\text { modernisation) }\end{array}$ & 150.00 & 1.50 & 1.00 \\
\hline 4 & $\begin{array}{c}41614 \mathrm{dd} \\
27.07 .2012\end{array}$ & $\begin{array}{l}\text { Dnipropetrovsk Metro } \\
\text { Construction Completion Project }\end{array}$ & 152.00 & 32.00 & 21.05 \\
\hline 5 & $\begin{array}{c}42086 \mathrm{dd} \\
25.03 .2013\end{array}$ & $\begin{array}{l}\text { Complex (Consolidated) Safety } \\
\text { Upgrade Program of Power Units } \\
\text { of Nuclear Power Plants }\end{array}$ & 300.00 & 297.86 & 99.29 \\
\hline 6 & $\begin{array}{c}40147 \mathrm{dd} \\
19.10 .2010\end{array}$ & $\begin{array}{l}750 \text { kV Zaporizhzhia Kakhovska } \\
\text { Line Project }\end{array}$ & 160.00 & 134.53 & 84.08 \\
\hline 7 & $\begin{array}{l}401885 \mathrm{dd} \\
26.11 .2010\end{array}$ & $\begin{array}{l}\text { Rehabilitation and improvement } \\
\text { of highways radiating from Kyiv } \\
\text { in central Ukraine }\end{array}$ & 450.00 & 372.43 & 82.76 \\
\hline \multicolumn{3}{|c|}{ TOTAL } & 1552.00 & 887.55 & 57.19 \\
\hline
\end{tabular}

Source: compiled by the author based on [19] 
The practice of raising funds from IFIs indicates a positive impact on the development of SME through lending, equity investments, guarantee instruments, issue bonds in local currency. For 20 years, the EBRD has been financing the Ukrainian SME with technical support from the EU, USAID, CIDA, Frontier Finance International (FFI) (USA), Internationale Projekt Consult GmbH (Germany), Development Finance International, Inc. (France), the governments of Canada and the Netherlands.

The World Bank (WB) is Ukraine's second-largest creditor. It consists of the International Bank for Reconstruction and Development (IBRD) and the International Development Association (IDA). During the cooperation with the World Bank, 55 loans totaling 12.24 billion USD were approbate for Ukraine, 9.5 billion USD of which was received. As of today, $44.8 \%$ of funds provided by the WB to Ukraine have been used to implement projects (see Table 4).

The case of growing Ukraine's external debt to IFIs is particularly risky (Figure 2). The actual issue is the stability of the exchange rate policy of Ukraine. Since the beginning of Ukraine's cooperation with IFIs, especially with the IMF, the liberalization of the NBU's exchange rate policy has intensified, together with the low institutional level of the monetary system development, the strengthening of foreign policy risks, foreign trade imbalance of Ukraine contributed to the substantial devaluation in 2013-2018 (Figure 3). Therefore, the priority should be to ensure the timely repayment of financial assistance to IFIs.

Among the problems in the field of monetary and financial cooperation of Ukraine with IFIs is the reduction of Ukraine's solvency; lack of balance of payments; growth of external debt; imbalance of macroeconomic conditions, and consequently, the deterioration of the investment climate in Ukraine; loss of purchasing power due to reduced revenues and rising inflation; low level of economic and political security of Ukraine; inefficient use of borrowed funds; corruption.

According to Klymenko K.V. [9], despite the long-established consistent statutory regulation system of cooperation with IFIs developed in Ukraine, attracted resources are not used efficiently due to lack of a strategic roadmap for reform in certain sectors; the need to amend legislation, lengthy procedures for the preparation of tender documents, considerable time for approval on land allocation; low institutional capacity of the responsible executor and beneficiaries of projects; lack of funds to pay VAT. 
Disbursement of funds for the World Bank projects in the public sector of Ukraine

\begin{tabular}{|c|c|c|c|c|}
\hline \multirow{2}{*}{ Project Title } & \multirow{2}{*}{\begin{tabular}{|c|} 
Loan \\
amount, \\
million \\
USD
\end{tabular}} & \multicolumn{2}{|c|}{$\begin{array}{l}\text { Disbursed at } \\
\text { April 1, 2020 }\end{array}$} & \multirow{2}{*}{$\begin{array}{l}\text { Closing date } \\
\text { of the project } \\
\text { (dd/mm/yyyy) }\end{array}$} \\
\hline & & $\begin{array}{c}\text { million } \\
\text { USD }\end{array}$ & $\%$ & \\
\hline $\begin{array}{l}\text { Second Roads and Safety Improvement } \\
\text { Project }\end{array}$ & 450 & 392.71 & 87.3 & 30.06 .2020 \\
\hline $\begin{array}{l}\text { Social Assistance System } \\
\text { Modernization Project }\end{array}$ & 300 & 161.558 & 53.9 & 01.10 .2020 \\
\hline Second Urban Infrastructure Project & 292.1 & 83.92 & 29.5 & 30.10 .2020 \\
\hline $\begin{array}{l}\text { District Heating Energy Efficiency } \\
\text { Project }\end{array}$ & 160 & 68.29 & 42.7 & 2020 \\
\hline $\begin{array}{l}\text { Second Power Transmission Project in } \\
\text { Ukraine }\end{array}$ & 270 & 66.2 & 24.6 & 30.06 .2020 \\
\hline $\begin{array}{l}\text { Serving People, Improving Health } \\
\text { Project }\end{array}$ & 214.73 & 127.32 & 59.3 & 30.09 .2020 \\
\hline Road Sector Development Project & 337.8 & 61.47 & 18.2 & 31.12 .2021 \\
\hline Access to Long Term Finance Project & 150 & 56.41 & 37.6 & 30.03 .2022 \\
\hline TOTAL & 2323.07 & 1040.84 & 44.8 & - \\
\hline
\end{tabular}

Source: compiled by the authors based on [20]

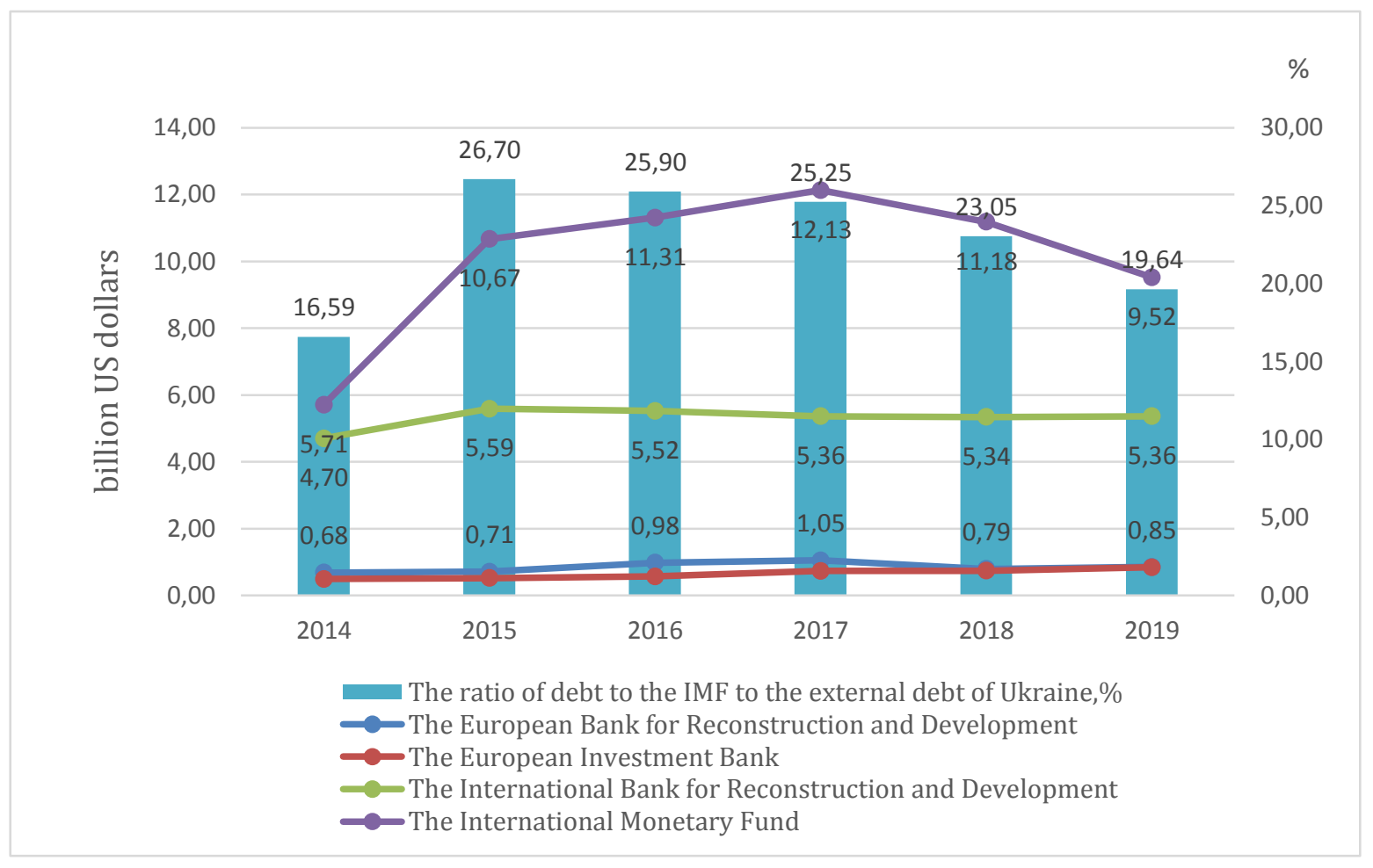

Figure 2. Ukraine's debt to IMF in 2014-2019

Source: compiled by the authors based on [21] 


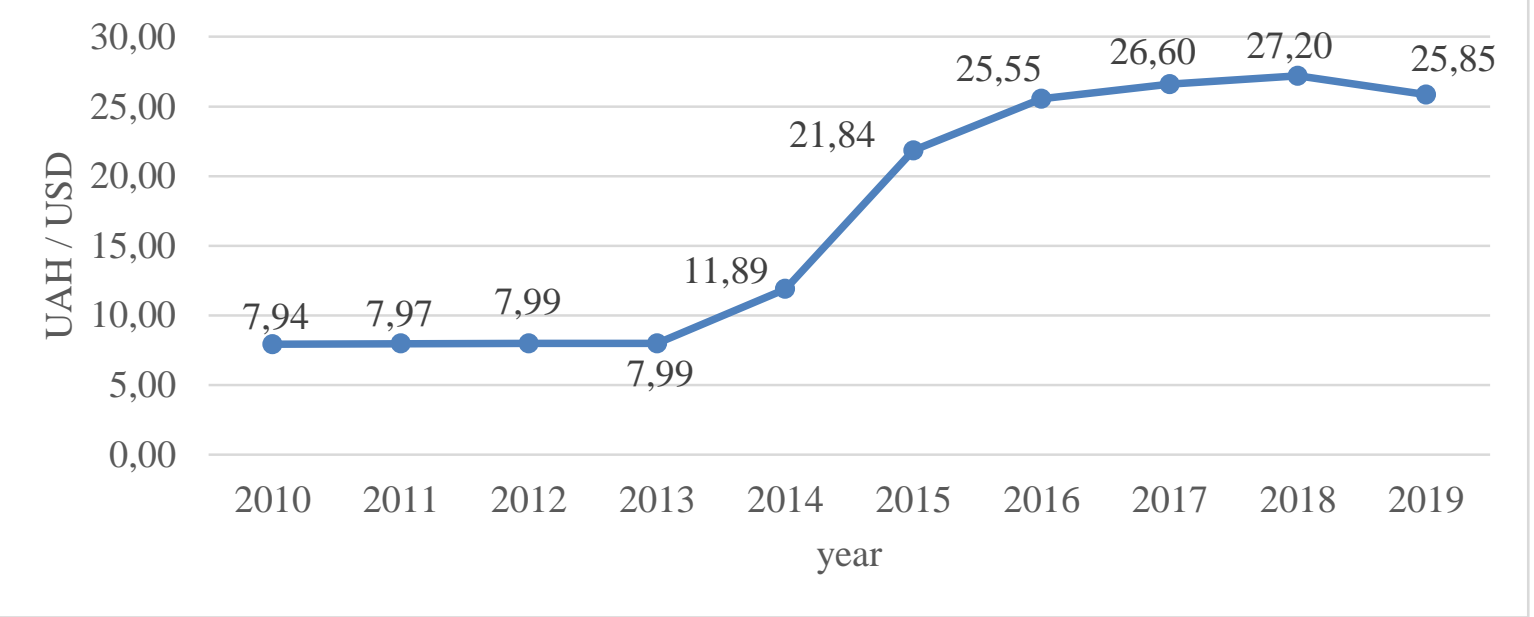

Figure 3. The nominal exchange rate for 2010-2019, UAH / USD

Source: compiled by the authors based on [22]

\section{Part 3. Agro-industrial complex of Ukraine within the system of International Organizations}

Agro-industrial complex of Ukraine (agro-industry) unites industries aimed at the production and processing of agricultural raw materials, obtaining finished products, as well as marketing and retail sales: agriculture itself; industries and services, providing agriculture by means of production and material resources; agro-processing industries; infrastructure unit.

The introduction of strategic development lines in the agro-industrial sector and the deepening of cooperation with IOs are taking place simultaneously. Ukraine is a member of 23 international organizations in the field of agriculture, forestry and fisheries.

Effective trading and ensuring the competitiveness of Ukrainian agribusiness products in the international market depends not only on cooperation with sectoral international organizations affecting the processes of production and processing of raw materials (the Food and Agriculture Organization of the United Nations (FAO), the International Union for the Protection of New Varieties of Plants (UPOV), the International Seed Testing Association (ISTA), the International Grains Council (IGC), and the International Sugar Organization (ISO); the International Organisation of Vine and Wine (OIV) and others (see Fig. 4, Table 4), but also with the institutions studied in the field of international trade (in particular, the WTO, the Black Sea Trade and Development Bank (BSTDB), the World Customs Organization, the Bureau of International Expositions (BIE), the United Nations Industrial Development Organization (UNIDO)).

Therefore, by the place in the value chain of a separate branch of production, in particular, in the agro-industrial complex, we offer to allocate IO directly influencing the production and processing of raw materials (including internal 
logistics and production process) and IOs providing effective development of foreign trade (external logistics, marketing and sales).

\begin{tabular}{|c|c|}
\hline $\begin{array}{l}\text { Ministry of } \\
\text { Agrarian Policy and } \\
\text { Food of Ukraine }\end{array}$ & $\begin{array}{l}\text { Food and Agriculture Organization of the United } \\
\text { Nations (FAO), International Union for the Protection } \\
\text { of New Varieties of Plants (UPOV) } \\
>\text { International Seed Testing Association (ISTA), } \\
>\text { International Grains Council (IGC) } \\
>\text { International Sugar Organization (ISO) } \\
>\text { International Organisation of Vine and Wine (OIV) }\end{array}$ \\
\hline $\begin{array}{l}\text { State Service } \\
\text { of Ukraine for } \\
\text { Food Safety and } \\
\text { Consumer } \\
\text { Protection }\end{array}$ & $\begin{array}{l}>\text { World Organization for Animal Health (OIE) } \\
\text { European and Mediterranean Plant Protection } \\
\text { Organization (EPPO) } \\
>\text { International Plant Protection Convention (IPPC / } \\
\text { IPPC) } \\
>\text { Commission on Phytosanitary Measures (CPM) }\end{array}$ \\
\hline $\begin{array}{l}\text { State Agency } \\
\text { for Fisheries of } \\
\text { Ukraine }\end{array}$ & $\begin{array}{l}>\text { Commission on the Conservation of Antarctic Marine } \\
\text { Living Resources (CCAMLR) } \\
>\text { Northwest Atlantic Fisheries Organization (NAFO) } \\
\text { International Commission for the Protection of the Danube } \\
\text { River } \\
>\text { Convention on Cooperation for the Protection and } \\
\text { Sustainable Use of the Danube River (ICPDR) }\end{array}$ \\
\hline $\begin{array}{l}\text { State Forest } \\
\text { Resources } \\
\text { Agency of } \\
\text { Ukraine }\end{array}$ & $\begin{aligned} & \text { FAO Committee on Forestry }(\mathrm{COFO}) \\
& \text { FAO European Forestry Commission (EFC) } \\
& \text { Ministerial Conference on the Protection of Forests in } \\
& \text { Europe (MCPFE) } \\
& \text { United Nations Forum on Forests (UNFF) } \\
& \text { UNECE Committee on Forests and the Forest Industry } \\
& (\text { COFFI) }\end{aligned}$ \\
\hline $\begin{array}{l}\text { State Service } \\
\text { of Ukraine for } \\
\text { Geodesy, } \\
\text { Cartography and } \\
\text { Cadastre } \\
\text { (StateGeo } \\
\text { Cadastre) }\end{array}$ & $\begin{aligned} & \text { Association of National Cartographic, Geodetic and } \\
& \text { Cadastral Services of European Countries } \\
& \text { (EuroGeographics) } \\
&>\text { UN Group of Experts on Geographical Names } \\
& \text { (UNGEGN) } \\
&>\text { International Cartographic Organization (ICA) } \\
&>\text { Interstate Council for Geodesy, Cartography, Cadastre } \\
& \text { and Earth Remote Sensing of the CIS member states } \\
&>\text { Technical Committee for Standardization of } \\
& \text { Geographical Information (ISO/TC 211) }\end{aligned}$ \\
\hline
\end{tabular}

\section{Figure 4. Cooperation of the central executive bodies of Ukraine with international organizations in the field of agribusiness}

Source: compiled by the authors based on [23] 


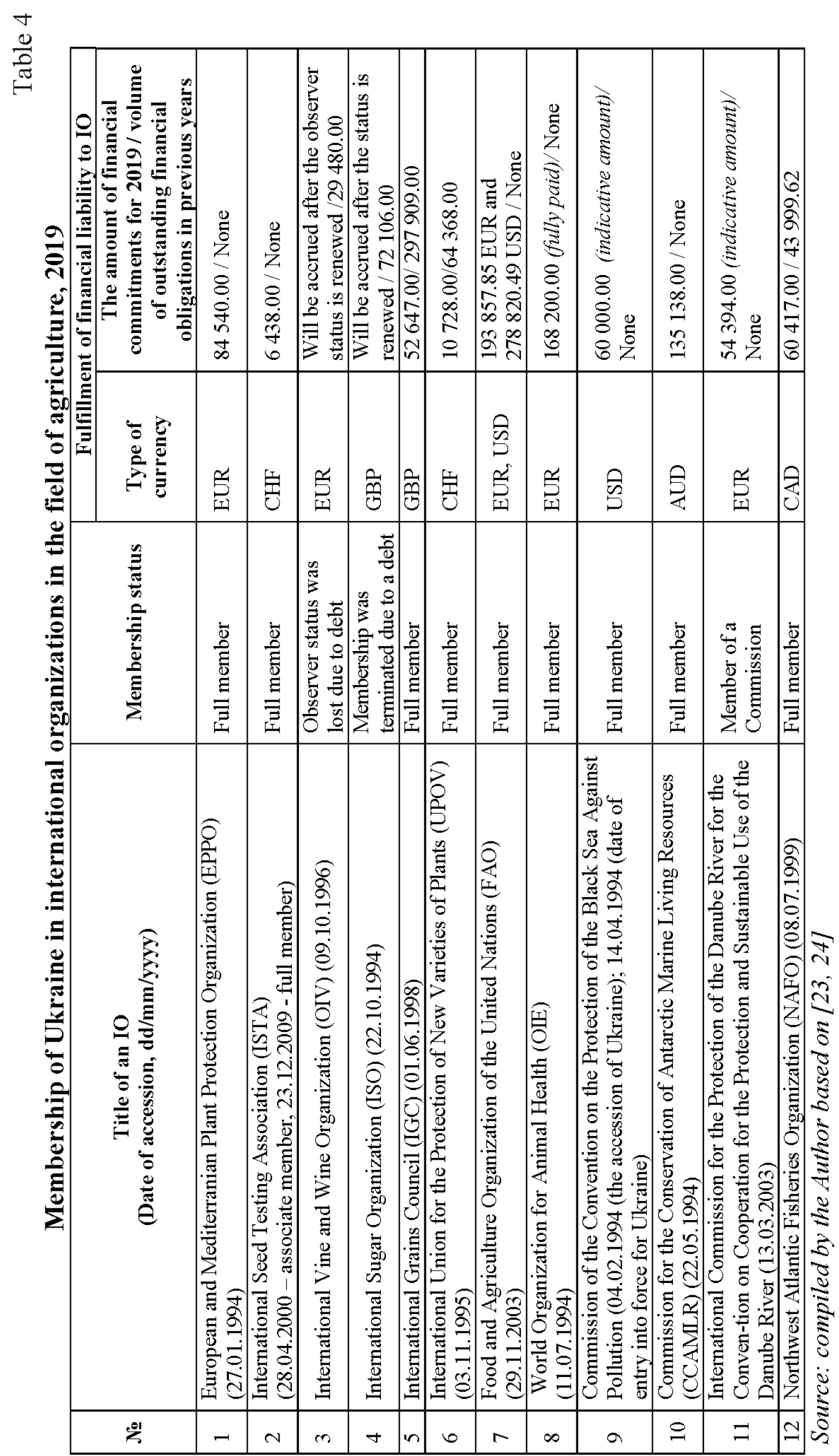


Ukraine works collaboratively with IO in the field of environmental protection (the WB, IBRD, EBRD, EIB, the Nordic Investment Bank (NIB), subnational finance from the International Finance Corporation (IFC), the Nordic Environment Finance Corporation (NEFCO), the Global Environment Facility (GEF), the Eastern Europe Energy Efficiency and Environment Partnership (E5P), the Swedish International Development Cooperation Agency (SIDA), the DemoUkrainaDH NEFCO Programme, the German Society for International Cooperation (GIZ), the Charles Stewart Mott Foundation, the Heinrich Boell Foundation) [10]. However, the opportunities for such cooperation are not fully used, due to the lack of motivation to intensify nature conservation and environment-related activities at the local communities' level and due to the shortcomings of the relevant domestic legislation, the lack of a comprehensive program to improve environmental performance.

In conditions of accelerated integration of countries, the protection of their population interests and the settlement of social and labour problems is relevant [7]. The leading role in this process is played by the International Labor Organization (ILO), which actively improves its program bases and international labor standards and mechanisms to lay the foundations of reliable protection of working people. In particular, a joint project of the EU Delegation to Ukraine and the ILO entitled «Towards safe, healthy and declared work in Ukraine» is to be implemented in 2020-2022.

The current standard-setting activities of international intergovernmental organizations of a global type are aimed at creating conditions of equal opportunities both at the level of countries and for all members of society within a single country in achieving the goals of human development, peace and security [5].

However, as Hodovanyk Ye.V. proves, strengthening the role of international organizations in countering acts of aggression as an important direction of their reform at the present stage should be carried out by institutional modernization of their structure and expansion of powers in accordance with the current international situation. Changes are possible in case of an international law-making consensus of the states with the greatest military-political and economic potential and other countries of the world based on the inviolable international legal principles of peaceful coexistence.

As it is known, the main reason for the UN low effectiveness in countering acts of military aggression is the right to veto resolutions of UN Security Council that is the UN body responsible for maintaining international peace and security in the world by its permanent members [6].

In view of this, in our opinion, it is expedient to allocate the appropriate criterion for classifying IOs, namely «compliance with changes in the international context». According to it, IOs can be divided into ones whose activities correspond to modern realities and those in need of reorganization. 


\section{Conclusions}

IOs actively interact with each other, form a single system and are an integral part of the international relations by virtue of promoting mutual integration of states, intensification of their economic growth, increase in the volume of common foreign trade due to the elimination of non-tariff and customs barriers, improvement in the global economy, participating countries financial sector development through direct investment.

International organizations, through a system of bodies with a defined structure and composition, perform a list of certain functions within their competences through decision-making in the prescribed manner and are funded mainly by contributions from member countries.

Today, there is an increasing role of international governmental and nongovernmental organizations in Ukraine and the world as a whole. In recent decades, monetary and financial cooperation between Ukraine and IFIs has become important. Minimization of the currency and debt risk factors of Ukraine in cooperation with IFIs by solving problems in the field of public administration will help to stabilize the economic and political situation, economic progress of the country, including the development of small and medium business, investment attractiveness and development of entrepreneurship, stabilization of financial and currency systems.

The effectiveness of Ukraine's cooperation with IO in the field of environmental protection depends on increasing the motivation to intensify nature conservation and environment-related activities at the local communities' level, improving domestic legislation, developing a comprehensive program to enhance environmental performance.

The implementation of joint projects with the International Labor Organization contributes to raising the level of protection of the interests of the population of Ukraine and resolving the problems of social and labor relations.

Deterioration of socio-economic development of Ukraine is associated with the system imperfection of the IOs in counteracting acts of aggression that requires immediate institutional modernization of their structure.

Given the results of the study of existing approaches to IO classification and having analysed current trends in their development as the subjects of international relations, including in the field of agriculture, taking into account the global downturn, we suggest supplementing the existing classification list with new criteria: «compliance with changes in the international context» (IOs whose activities correspond to modern realities and those in need of reorganization), «a place in the value chain of products of a certain industry» (IOs directly affecting the production and processing and those ensuring the effective development of foreign trade in the industry). 


\section{References:}

1. Baluta I. V. (2017) Analiz diyalnosti mizhnarodnykh neuryadovykh orhanizatsiy v umovakh hlobalizatsiyi [Analysis of international NGOs in the context of globalization]. Current issues of public administration, no 1, pp. 106-112. Available at: http://nbuv.gov.ua/UJRN/apdy_2017_1_18

2. Ryneiska L. S. (2018) Rol mizhnarodnykh orhanizatsiy u formuvanni mizhnarodnykh stratehiy ekonomichnoho rozvytku [The role of international organizations in shaping international economic development strategies]. Efektyvna ekonomika [Efficient Economy] (electronic journal), no. 3. Available at: http://www.economy.nayka.com.ua/ pdf/3_2018/56.pdf (accessed 15 June 2020).

3. Sazonets I. L., Sipailo N. A. (2016) Rol neuryadovykh orhanizatsiy u systemi rehulyuvannya mizhnarodnykh ekonomichnykh vidnosyn [The role of NGOs in the regulation of international economic relations]. Bulletin of National University of Water Management and Environmental Sciences (Ukraine, Rivne), Series «Economic Sciences», vol. 3(75).

4. Khomaiko K. (2018) Spivrobitnytstvo orhaniv publichnoyi vlady z mizhnarodnymy orhanizatsiyamy: naukovyy dyskurs [Cooperation of public authorities with international organizations: scientific discourse]. Public Administration and Local Self-Government, vol. 4(39).

5. Horbatiuk Ye. (2017) Mizhnarodni mizhuryadovi orhanizatsiyi hlobal'noho typu u systemi zabezpechennya sotsiohumanitarnoyi bezpeky [International intergovernmental organizations of global type in the system of socio-humanitarian security]. Bulletin of NAPA under the President of Ukraine (Ukraine, Kyiv, Series "Public Administration», vol. 3'2017, p.78.

6. Hodovanyk Ye.V., Pokatovych M.O. (2017) Posylennya roli mizhnarodnykh orhanizatsiy u protydiyi aktam ahresiyi yak vazhlyvyy napryam yikh reformuvannya na suchasnomu etapi [Strengthening the role of international organizations in counteracting acts of aggression as an important direction of their reform at the present stage]. Bulletin of Mariupol State University (Ukraine, Mariupol), Series «Law», vol. 13, p. 67.

7. Dereval Yu. (2017) Fundamentalni zasady diyal'nosti mizhnarodnoyi orhanizatsiyi pratsi $\mathrm{v}$ umovakh hlobalizatsiyi [Fundamental principles of the international labor organization in the context of globalization]. The Scientific Papers of the Legislation Institute of the Verkhovna Rada of Ukraine (Ukraine, Kyiv), vol. 6/2017, p. 55.

8. Zamkovyi R.V. (2019) Spivrobitnytstvo Ukrayiny z mizhnarodnoyu orhanizatsiyeyu zi standartyzatsiyi [Cooperation of Ukraine with the International Organization for Standardization]. The Scientific Papers of the Legislation Institute of the Verkhovna Rada of Ukraine (Ukraine, Kyiv), vol. 1/2019, p. 104.

9. Klymenko K.V., Savostianenko M.V. (2018) Zabezpechennya rezul'tatyvnosti realizatsiyi $\mathrm{v}$ Ukrayini proektiv $\mathrm{z}$ vykorystannyam resursiv mizhnarodnykh finansovykh orhanizatsiy [Ensuring the effectiveness of projects in Ukraine using the resources of international financial organizations]. RFI Scientific Papers, no. 3(84), p.102.

10. Kolosova M. P. (2018) Spivrobitnytstvo Ukrayiny $z$ mizhnarodnymy orhanizatsiyamy u sferi finansuvannya pryrodookhoronnoyi ta ekolohichnoyi diyal'nosti [Cooperation of Ukraine with international organizations in the field of financing conservation and environmental activities]. RFI Scientific Papers, no. 2(83), p. 146.

11. Tereshchenko H. M., Kaplenko O. I., Severina Kh. I. (2017) Problemy ta perspektyvy zaluchennya resursiv mizhnarodnykh finansovykh orhanizatsiy [Problems and prospects of attracting resources from international financial institutions]. RFI Scientific Papers, no. 3(80), p. 111. 
12. Kozak YU. H., Kovalevskyi V. V., Lohvinova N. S. (ed.) (2009) Mizhnarodni orhanizatsiyi [International Organizations] (textbook). Kyiv: Tsentr Navchalnoii Literatury (Educational Literature Centre), 223 p., p. 13. (in Ukrainian)

13. Skrypnyk O. M. (2011) Istoriia mizhnarodnykh orhanizatsii [The history of international organizations] (textbook). Uman: PP Zhovtyi O.O. (in Ukrainian)

14. Zaplitna T. V. (2018) Stratehiyi ta osoblyvosti diyalnosti mizhnarodnykh kredytnofinansovykh orhanizatsiy $\mathrm{v}$ Ukrayini [Strategies and features of international credit and financial organizations in Ukraine]. Scientific Journal, vol. 6, p. 132.

15. About 80 countries asked the IMF for financial assistance in the fight against coronavirus (electronic resource). Available at: https://zik.ua/news/economics/blyzko_ 80_krain_prosiat_mvf_pro_finansovu_dopomohu_v_borotbi_z_koronavirusom_964121

16. IMF eased the debt burden to 25 countries through COVID-19 (electronic resource). Available at: https://hromadske.ua/posts/mvf-polegshiv-borgovij-tyagar-dlya25-krayin-svitu-cherez-koronavirus

17. Ministry of Finance of Ukraine. The International Monetary Fund (electronic resource). Available at: https://mof.gov.ua/uk/mvf

18. Ministry of Finance of Ukraine. The European Investment Bank (electronic resource). Available at: http://www.menr.gov.ua/international/international2/180-yeib

19. Ministry of Finance of Ukraine. The European Bank for Reconstruction and Development (electronic resource). Available at: https://mof.gov.ua/uk/ebrr

20. Ministry of Finance of Ukraine. The World Bank (electronic resource). Available at: http://www.minfin.gov.ua/control/uk/pu blish/article?art_id=388308\&c at_id =3531

21. Ministry of Finance of Ukraine [official web site]. Available at: http://www.minfin.gov.ua

22. The National Bank of Ukraine [official web site]. Available at: https://www.bank.gov.ua

23. Resolution of the Cabinet of Ministers of Ukraine of September 13, 2002, № 1371. On the procedure for participation of central executive bodies in the activities of international organizations of which Ukraine is a member. Available at: https://zakon.rada.gov.ua/ laws/show/1371-2002-\%D0\%BF\#Text

24. The Unified State Register of International Organizations of which Ukraine is a Member (as of 08.2019). Available at: https://mfa.gov.ua/ua/about-ukraine/internationalorganizations/io-register 